EESTI NSV TEADUSTE AKADEEMIA TOIMETISED. 32. KOIDE

FOOSIKA * MATEMAATIKA!' 1983, NR. 1

ИЗВЕСТИЯ АКАДЕМИИ НАУК ЭСТОНСКОИ ССР. ТОМ 32 ФИЗИКА * МАТЕМАТИКА, 1983, № 1

\title{
HARMONIC REDUCTION IN AC VOLTAGE CONTROLLERS BY MEANS OF INTERPHASE TRANSFORMATION-RATIO MODULATION
}

(Presented by I. Opik)

\begin{abstract}
A novel phase-control technique using an interphase variable-ratio transformer to reduce distortions in AC voltage controllers is presented and corresponding new power circuits are proposed. Their operating principle is based on a suitable stepped modulation of the interphase transformation ratios that permit the proper interphase energy exchange control essential for eliminating lower distortion harmonics.
\end{abstract}

\section{Introduction}

The phase-control of load-voltage is based on the alteration of reactive voltage drop across a controlling element connected in series both with the load and the voltage supply $\left[{ }^{1,2}\right]$. If such a series controller employs switches as basic power conversion elements, the generation of distortion harmonics is inevitable $\left[{ }^{2,3}\right]$. To reduce the unwanted harmonics to an acceptable level, to localize them inside the power converter, and, as a result, to improve the waveforms both of input and load currents, most often reactive filters, high frequency links and phase multipliers have been used $\left[{ }^{4-7}\right]$. In the latter use, from the point of view of energy flow, cancellation of lower harmonics results from the proper interphase energy exchange. If the interphase energy transfer process essential for eliminating lower harmonics can be realized with less complicated elements than multi-winding transformers for phase multiplication, we shall obtain new promising power converters, including new advantageous AC voltage controllers. There are probably several ways for implementing the corresponding mode of interphase energy exchange. For example, the injection of current harmonics has been used $\left[{ }^{8}\right]$.

As shown recently $\left[{ }^{2,9,10}\right]$, another way to ensure the proper interphase energy flow essential for lower harmonic elimination is using a controlled interphase transformer. Power circuits of various static converters utilizing a simple one-core tapped autotransformer with a synchronous tap-changer have been presented $\left[{ }^{10-12}\right]$. In those circuits, however, forced commutation of switches is needed.

In this paper two new types of power circuits of an AC voltage controller using interphase energy exchange are proposed and discussed. Their advantage is a smaller number of necessary switches and natural commutation. 


\section{Basic circuits}

The proposed two new types of AC voltage controller circuits using a three-phase interphase autotransformer AT or transformer TR are shown in Figs $1, a$ and $1, b$, respectively. In both circuits the interphase transformer or autotransformer is connected in series with a symmetrical three-phase load. Various types of load can be used, e. g. linear or nonlinear AC load, primary windings of a power transformer in the circuit shown in Fig. 1, $a$, an uncontrolled rectifier bridge in the circuit shown in Fig. 1, $b$.

Tapped windings are used in the autotransformer and in the secondary of the transformer to enable the stepped modulation of the interphase transformation ratio. The positions of taps must be chosen so that, in the case of all switches opened, voltages across the switches would be shifted by $2 \pi / p$, where $p$ is the pulse number of the conversion circuit. $p / 2$ bidirectional or $p$ unidireçtional tap-changing switches are needed to implement the proper tap switching sequence.

In Fig. 1, $a$ a twelve-pulse and in Fig. 1, $b$ an eighteen-pulse circuits are shown. They permit to eliminate lower harmonics up to the 11th and the 17 th harmonic, respectively.

The circuit using an autotransformer has the advantage of lower rated volt-amperes of the electromagnetic equipment, but since all the six terminals of the three-phase load must be accessible, no rectifier bridge can be used as a load.

The circuit using a transformer with separated primary and secondary windings permits to match the supply and switch voltages as well as to connect the load through three terminals.

The switches both with natural and forced commutation can be used, but in the first case, the control is possible only with a lagging current. If fully-controllable switches, i. e. with turn-on and turn-off control capability, are employed, the control both with a lagging and leading current will be available.

At least one switch is conducting in both circuits during the operation. The sequence of switching on corresponds to the sequence of
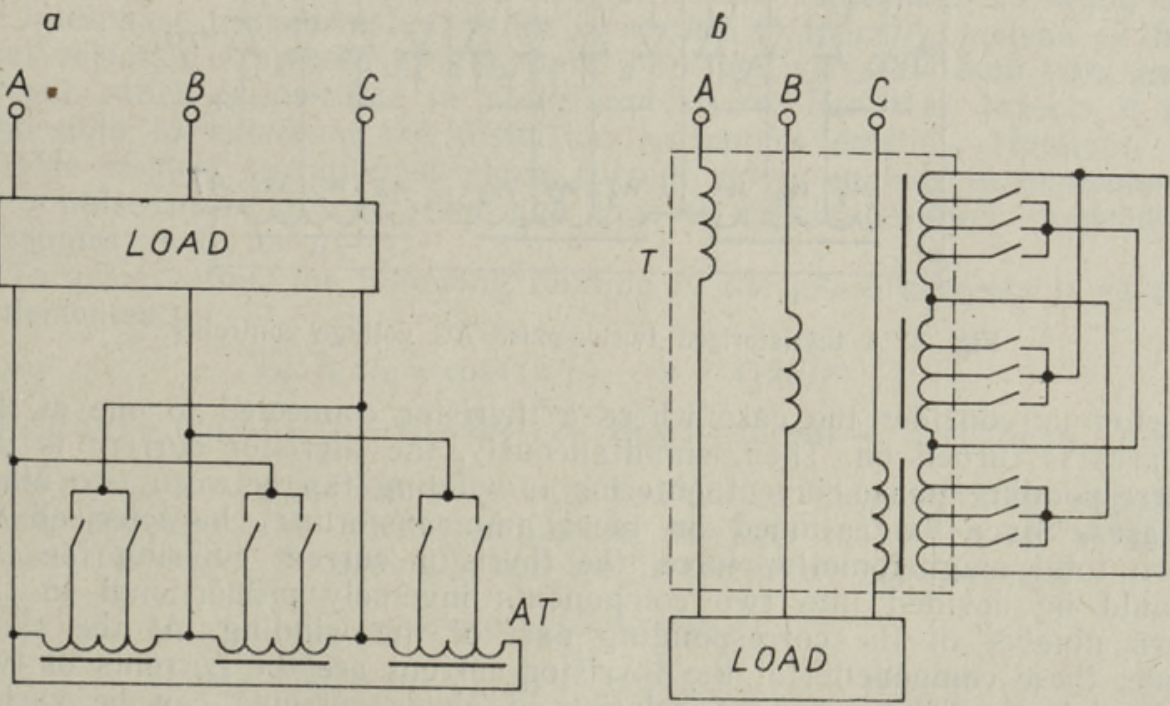

Fig. 1. AC voltage controller power circuits using an interphase autotransformer AT $(a)$ or an interphase tranșormẹr TR $(b)$. 
the voltages across the switches for all switches open. The appropriate sequence of switching on together with proper tap positions enable to form an output voltage waveshape containing no lower harmonics up to $h=k p \pm 1$, where $k$ is an integer.

As in other phase-controlled circuits, the fundamental component of the load voltage can be varied by shifting the turn-on instants of the switches.

\section{Operating principle}

To explain the operating principle of the power circuits (Fig. 1, $a$ and Fig. $1, b)$, let us assume that

1) sinusoidal supply voltages $u_{A}, u_{B}, u_{C}$ form a symmetrical threephase system and $u_{A}=U \cos \omega t$;

2) the symmetrical load is purely resistive;

3) the autotransformer and transformer are ideal;

4) bidirectional switches are realized by using ideal thyristors $T 1-T 12$ in an inverse-parallel connection.

The corresponding twelve-pulse power circuit is shown in Fig. 2. Winding tapping is made so that, in the case of all thyristors turned off, the thyristor voltages $u_{T 1}, \ldots, u_{T 12}$ form a twelve-phase symmetrical system as shown in Figs $3, a$ and $3, b$.

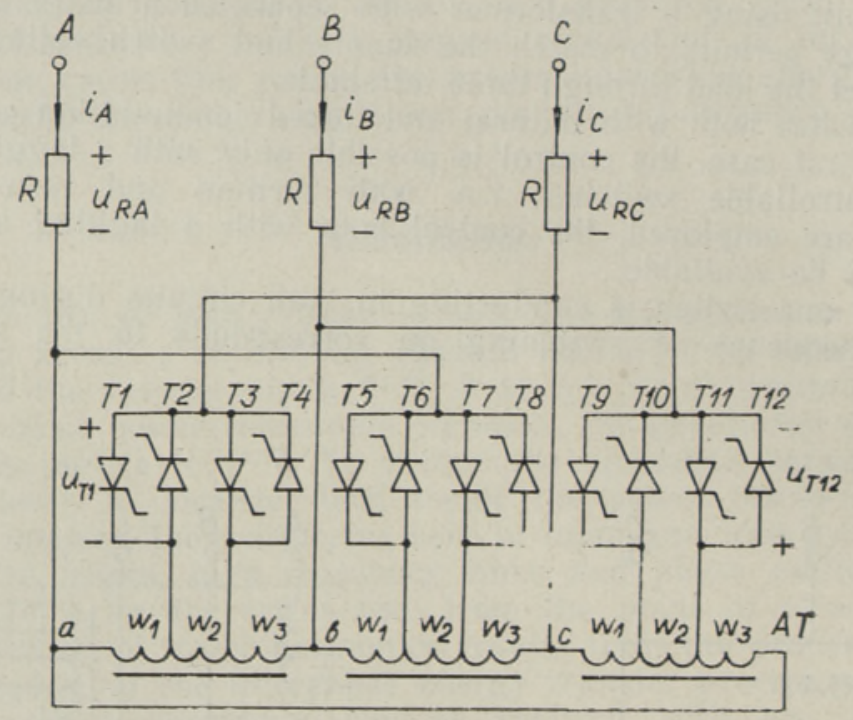

Fig. 2. A thyristorized twelve-pulse AC voltage controller.

Let us consider the case where a thyristor connected to one of the phases is turned on. Then, simultaneously, the thyristor current is the corresponding phase current entering a winding tap between two other phases. Since we assumed an ideal autotransformer characterized by zero total magnetomotive force, the thyristor current entering the tap would be devided into two components inversely proportional to the turn number of the corresponding part of the winding. At the same time, these components of the thyristor current are the currents of two other phases. Therefore, the relation of phase currents can be varied by changing tap positions. As a result, the phase current waveform can be smoothed by proper switching of taps. 
$a$

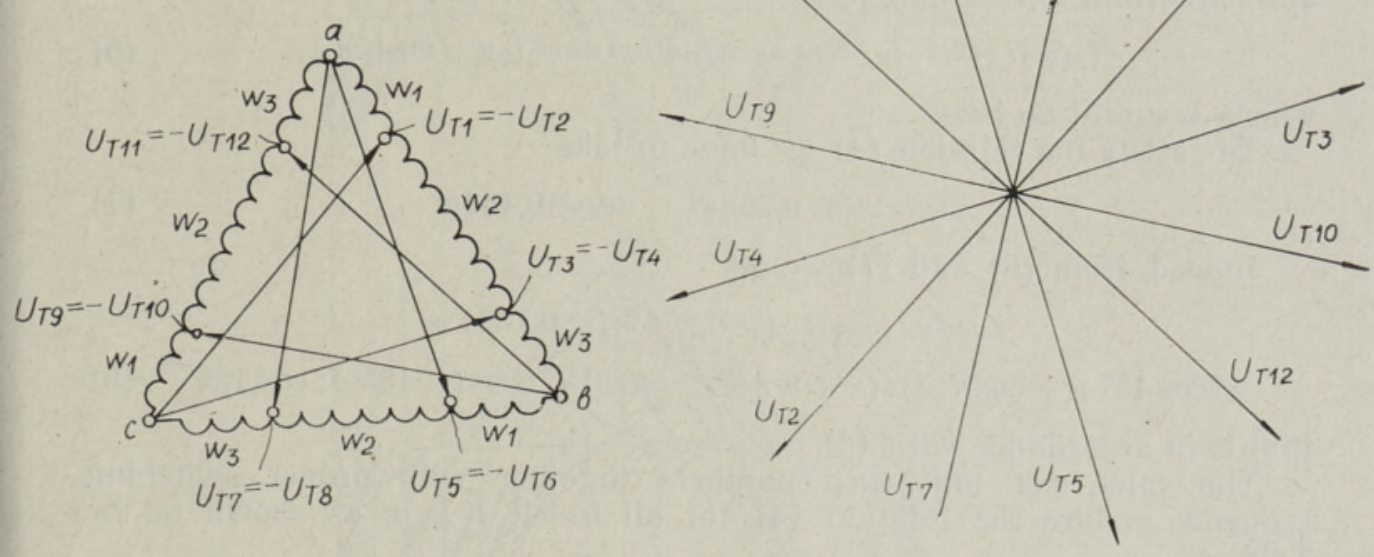

Fig. 3. Thyristor-voltage phasors $(a)$ and the corresponding phasor diagram $(b)$ for all thyristors nonconducting.

If there exist no distortion harmonics and the phase currents are sinusoidal, their relations change as follows:

$$
\begin{gathered}
i_{A}: i_{B}: i_{C}=u_{R A}: u_{R B}: u_{R C}= \\
=\cos (\omega t+\varphi): \cos (\omega t+\varphi-2 \pi / 3): \cos (\omega t+\varphi+2 \pi / 3),
\end{gathered}
$$

where voltage across the resistive load in the phase $A$

$$
u_{R A}=U \cos \varphi \cos (\omega t+\varphi) \text {. }
$$

Of course, to implement the relation (1), a continuous variation of the interphase transformation ratios is needed. Practically, instead of the ideal variation expressed by (1), only a stepped variation both taps and current ratios is possible in static converters. For that reason, it is impossible to eliminate the distortion harmonics entirely. However, a suitable stepped variation of phase current ratios enables to implement the $p$-pulse mode of operation and thus to eliminate lower distortion harmonics up to $h=p-1$.

To achieve this, the following relation of the phase currents is to be implemented:

$$
\begin{gathered}
i_{A}: i_{B}: i_{C}=\cos ((\pi / p)+(n-1) 2 \pi / p): \\
: \cos ((\pi / p)-(2 \pi / 3)+(n-1) 2 \pi / p): \cos ((\pi / p)+(2 \pi / 3)+(n-1) 2 \pi / p),
\end{gathered}
$$

where $n=1,2, \ldots, p$. Each state is to last during $1 / p$ part of the supply period, and the state corresponding to $n=1$ is to switch on at the moment $t=-\varphi / \omega$. Accordingly, for the twelve-pulse case we get

$$
\begin{gathered}
i_{A}: i_{B}: i_{C}=\cos \left[15^{\circ}+(n-1) 30^{\circ}\right]: \\
: \cos \left[-105^{\circ}+(n-1) 30^{\circ}\right]: \cos \left[135^{\circ}+(n-1) 30^{\circ}\right] .
\end{gathered}
$$

To determine the per unit turns of the windings, we consider the case with only thyristor $T 7$ conducting. Then the current $i_{A}=i_{T 7}$ enter- 
ing the tap is divided into two components $-i_{B}$ and $-i_{C}$ in windings $w_{1}, w_{2}$ and $w_{3}$, respectively. Hence, and taking into account the assumption of the ideal autotransformer, we get

$$
i_{C}=i_{B}\left(w_{1}+w_{2}\right) / w_{3}
$$

and, accordingly,

$$
i_{T 7}=i_{A}=-i_{B}-i_{C}=-i_{B} w / w_{3}=-i_{C} w /\left(w_{1}+w_{2}\right),
$$

where $w=w_{1}+w_{2}+w_{3}$.

To satisfy the relation (4) we have to take

$$
w_{1}=w_{3}=0,268 w, \quad w_{2}=0,464 w .
$$

Indeed, from (6) and (7) we get

$$
\begin{gathered}
i_{A}: i_{B}: i_{C}=1:(-0,268):(-0,732)= \\
=\cos 15^{\circ}:\left(-\cos 75^{\circ}\right):\left(-\cos 45^{\circ}\right)=\cos 15^{\circ}: \cos \left(-105^{\circ}\right): \cos 135^{\circ},
\end{gathered}
$$

that is in accordance with (4) for $n=1$.

The same per unit turn numbers together with proper switching sequence ensure the relation (4) for all $n=1, \ldots, p$, as shown in the Table.

Variation of the phase current relations in the twelve-pulse controller circuit

\begin{tabular}{r|c|c|c}
\hline$n$ & $\begin{array}{l}\text { Thyristor } \\
\text { conducting }\end{array}$ & $i_{A}: i_{B}: i_{C}=u_{R A}: u_{R B}: u_{R C}$ & $u_{R A}$ \\
\hline & 7 & $1:(-0,268):(-0,732)$ & $U \cos 15^{\circ} \cos \left(\omega t-15^{\circ}\right)=u_{\mathrm{I}}$ \\
2 & 7 & $0,732: 0,268:(-1)$ & $U \cos 45^{\circ} \cos \left(\omega t-45^{\circ}\right)=u_{\mathrm{II}}$ \\
3 & 2 & $0,268: 0,732:(-1)$ & $U \cos 75^{\circ} \cos \left(\omega t-75^{\circ}\right)=u_{\mathrm{III}}$ \\
4 & 9 & $-0,268: 1:(-0,732)$ & $U \cos 75^{\circ} \cos \left(\omega t+75^{\circ}\right)=u_{\mathrm{IV}}$ \\
5 & 11 & $-0,732: 1:(-0,268)$ & $U \cos 45^{\circ} \cos \left(\omega t+45^{\circ}\right)=u_{\mathrm{V}}$ \\
6 & 6 & $-1: 0,732: 0,268$ & $U \cos 15^{\circ} \cos \left(\omega t+15^{\circ}\right)=u_{\mathrm{VI}}$ \\
7 & 8 & $-1: 0,268: 0,732$ & $u_{\mathrm{I}}$ \\
8 & 1 & $-0,732:(-0,268): 1$ & $u_{\mathrm{II}}$ \\
9 & 3 & $-0,268:(-0,732): 1$ & $u_{\mathrm{III}}$ \\
10 & 10 & $0,268:(-1): 0,732$ & $u_{\mathrm{IV}}$ \\
11 & 12 & $0,732:(-1): 0,268$ & $u_{\mathrm{V}}$ \\
12 & 5 & $1:(-0,732):(-0,268)$ & $u_{\mathrm{VI}}$
\end{tabular}

It must be pointed out that the same relation of the phase currents

$$
1:(-0,732):(-0,268)=\cos 15^{\circ}:\left(-\cos 45^{\circ}\right):\left(-\cos 75^{\circ}\right)
$$

holds for all $n=1, \ldots, p$, only the particular phases with the maximum, intermediate or minimum level of current, correspondingly, change from state to state.

Moreover, as it can be seen from the Table, for states with $n$ and $n+6$, the phase current relations are exactly the same; only the directions of phase currents are different.

The voltages $u_{\mathrm{I}}, u_{\mathrm{II}}, \ldots, u_{\mathrm{VI}}$ may be regarded as potential levels of the load voltage, which can be chosen and implemented through turning on the corresponding thyristors.

In the state where at least two switches are conducting, the supply phase voltages appear across the load, while in the state with all switches nonconducting, the load voltages equal to zero.

As a result, the circuit shown in Fig. 2 permits to form the load voltage $u_{R A}$ waveshape, using eight voltage levels: $0, u_{A}, u_{\mathrm{I}}, u_{\mathrm{II}}, \ldots$ $\ldots, u_{\text {VI }}$. As an example, the formation of the load voltage waveshape 


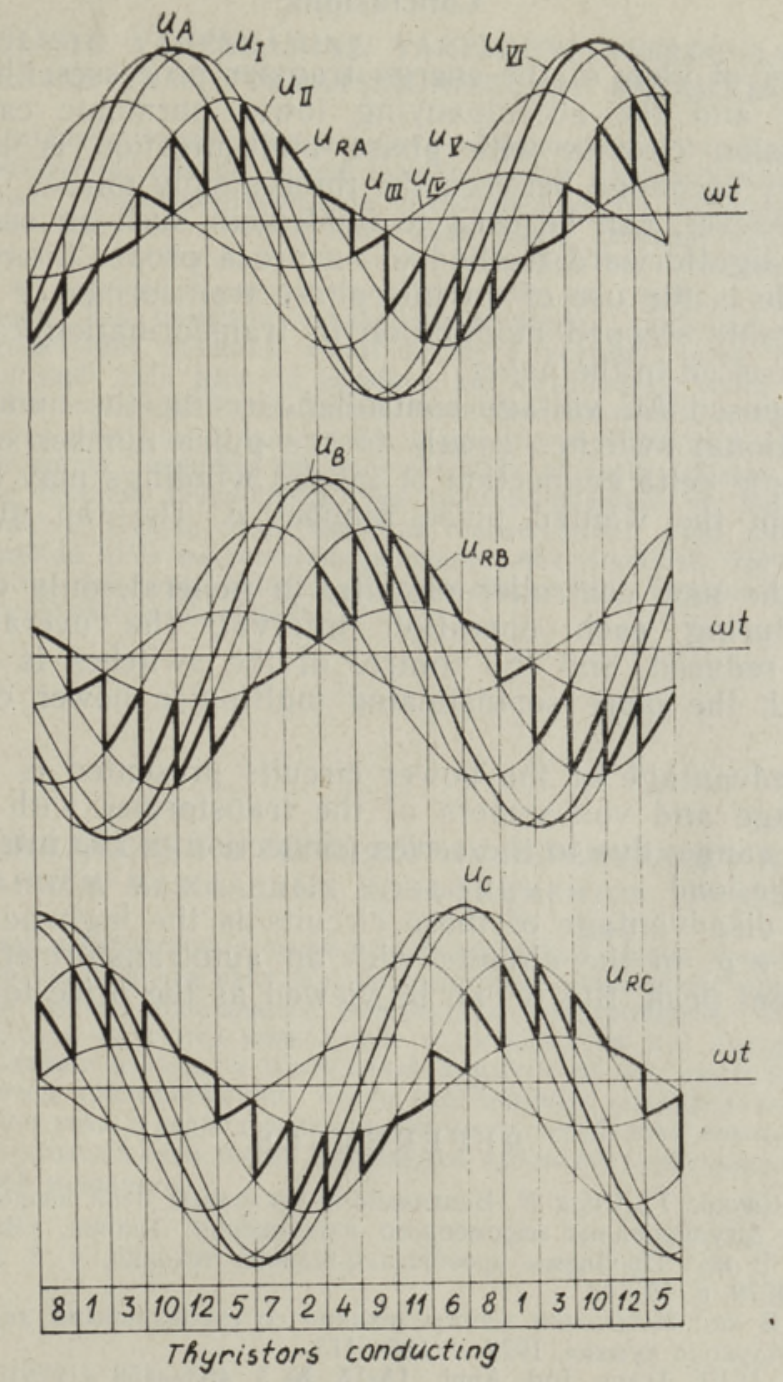

Fig. 4. Load voltage waveforms of the twelve-pulse AC voltage controller.

for the control angle $\alpha=60^{\circ}$ is shown in Fig. 4, where six voltage levels $u_{\mathrm{I}}, \ldots, u_{\mathrm{VI}}$ are used.

The operating principle of the circuit shown in Fig. $1, b$ is similar to that of the circuit shown in Fig. 1, $a$. In both cases the turning on of various switches enables to generate a set of potential load voltages. The actual load-voltage waveforms are composed of properly selected segments of the potential load voltages by controlling the switching sequence.

The main difference between the operation of the circuits with an autotransformer (Fig. 1, $a$ ) and a transformer (Fig. 1, $b$ ) is that the transformer windings are loaded continuously, whereas the corresponding time for autotransformer windings comprises only $1 / 3$ of the supply period.

Experimental verification of the proposed schemes both for resistive and resistive-inductive loads was carried out in the laboratory. 


\section{Conclusions}

From the point of view of the energy transfer processes, the increase of pulse number and the accompanying lower harmonic cancellation in power conversion circuits with phase multiplication is based on the suitable energy exchange between the three supply phases. Several other techniques, however, can be used to implement such an energy transfer process. A straightforward method to ensure a proper interphase energy exchange mode is the use of an interphase transformer or autotransformer with suitable stepped modulation of transformation ratios, as proposed and discussed in the paper.

In the proposed AC voltage controller circuits, the number of necessary unidirectional switches equals to the pulse number of the circuit. The same simple delta connection of tapped windings may be used independently from the wanted pulse number $p$. The tap number equals to $p / 2$.

Since in the new controller circuits, in general, only one switch is conducting during each operation interval, the overall losses in switches are reduced, and the control of the switches is simplified as compared with the more sophisticated multipulse power controller circuits.

A futher advantage of the power circuits presented is the reduction of rated voltage and volt-ampers of the transformer with the decrease of the control range, due to the series connection of the interphase transformer with the load.

A certain disadvantage of these circuits is the high peak current of the switches, e.g. in the circuits with an autotransformer it equals to the load current peak. But it can be viewed as the price for the benefits derived.

\section{REFERENCES}

1. Оявеэр М., Саккос T., Сарв В. Вентильно-индуктивные цепи непрерывного амплитудного регулирования переменного напряжения. Таллин, «Валгус», 1978.

2. Сарв В. В. В кн.: Проблемы преобразовательной техники, ч. 3. Киев, ИЭД АН УCCP, 1979 , c. $10-13$.

3. Сарв $B$. B. В кн.: Источники электропитания со специальными характеристиками. Киев, «Наукова думка», 1979, с. 106-113.

4. Shipp, D. D. IEEE Trans. Ind. Appl., IA-15, № 5, 453-458 (1979).

5. Gyugyi, L., Pelly, B. R. Static power frequency changers. Wiley-Interscience, New York, 1976.

6. Gyugyi, L., Cibulka, F. IEEE Trans. Ind. Appl., IA-15, № 4, 420-429 (1979).

7. Stratford, R. P. IEEE Trans. Ind. Appl., IA-17, № 1, 71-81 (1981).

8. Baird, J. F., Arrilaga, J. IEE Proc., 127, Pt. C, № 5, 294-303 (1980).

9. Сарв В. В. В кн.: Электромагнитное совмещение силовых полупроводниковых преобразователей. Таллин, АН ЭССР, 1981, с. 103-109.

10. Sarv, V. In: 4th Power Electronics Conference Budapest 81. III Static Energy Converters. Budapest, OMKDK-Technoinform, 1981, p. 117-127.

11. Сарв В. В., Ранне Н. Э., Сооярв Ю. Э., Суй Р. Х. Авт. свид. СССР № 851361. Бюл. изобр. № 28 (1981).

12. Сарв В. В., Ранне И. Э., Сооярв Ю. Э. Авт. свид. СССР № 873223. Бюл. изобр. № 38 (1981).

Academy of Sciences of the Estonian SSR, Institute of Thermophysics and Electrophysics

Received May 4, 1982 


\title{
V. SARV
}

\section{HARMOONILISTE VÄHENDAMINE VAHELDUVPINGEREGULAATORITES FAASIDEVAHELISE TRANSFORMATSIOONITEGURI MODULEERIMISE TEEL}

On esitatud kolmefaasise vahelduvpinge sujuva vähemoonutava faasireguleerimise uued perspektiivsed jõuskeemid, mis põhinevad faasidevahelise transformatsiooniteguri astmelisel moduleerimisel. Reguleerimisskeemide põhielemendid on faasidevahelist energiavahetust 'võimaldav trafo või autotrafo ning seda juhtiv (mähiste väljavōtteid sobivas rütmis perioodiliselt ümberühendav) staatiline kommutaator. Uute skeemide tööpōhimõttest nähtub, et vajalike ühesuunaliste lülitite arv on võrdne vooluhüpete arvuga skeemi toiteperioodil. Kui kasutada vabakommutatsiooniga sulguvaid lüliteid, siis on väljundpinge reguleerimine võimalik ainult hilistuva voolugá, kuna täielikult juhitavate lülitite puhul saab seda teha nii edestava kui ka hilistuva voolu režiimis.

Uued skeemid võimaldavad madalamaid moonutusharmoonilisi koormusvoolust kõr. valdada inertseid reaktiivelemente kasutamata, nagu see on võimalik ka üldtuntud faasipaljundusskeemide korral. Seejuures on uute skeemide oluliseks eeliseks trafo või autotrafo lihtsus ning väiksem tüüpvõimsus. See tuleneb asjaolust, et uute skeemide töö ei põhine suurendatud faaside arvu tegelikul realiseerimisel, vaid üksnes senituntud paljufaasiliste skeemide tööle iseloomuliku ja moonutusharmooniliste kõrvaldamise seisukohast olulise kolme toitefaasi vahelise energiavahetusrütmi tagamisel, kusjuures see toimub võimalikult lihtsalt ja säästlikult.

\section{B. $C A P B$}

\section{УМЕНЬШЕНИЕ ИСКАЖЕНИИ В РЕГУЛЯТОРАХ ПЕРЕМЕННОГО НАПРЯЖЕНИЯ МОДУЛИРОВАНИЕМ МЕЖФАЗНЫХ КОЭФФИЦИЕНТОВ ТРАНСФОРМАЦИИ}

\begin{abstract}
Предложены новые перспективные вентильно-индуктивные схемы фазового регулирования трехфазного переменного напряжения, в которых уменьшение искажающих гармоник достигается путем подходящего межфазного энергообмена. Основными элементами силовых схем являются межфазный трансформатор или автотрансформатор, обмотки которых имеют отводы, и вентильный коммутатор для периодического изменения коэффициентов трансформации. Число необходимых однонаправленных ключей равно числу скачков тока в период питания. Возможна свободная коммутация ключей. От известных многофазных схем новые отличаются простотой трансформатора и уменьшением его типовой мощности.
\end{abstract}

